\title{
First occurrence of Lepomis gibbosus $(L ., 1758)$ in the Segura river basin (SE, Spain)
}

\author{
Francisco J. Oliva-Paterna, Asunción Andreu, David Verdiell \& Mar Torralva \\ Department of Zoology. University of Murcia. 30100 Murcia. Spain. fjoliva@um.es
}

\section{RESUMEN}

Este trabajo constituye la primera cita de Lepomis gibbosus (L.,1758) en la Cuenca del río Segura (SE, España). La presente comunicación amplía la distribución geográfica de L. gibbosus en la Península Ibérica con la inclusión de la Cuenca hidrológica del Segura en su rango de distribución. Este trabajo presenta la primera cita de la presencia de la especie en la Cuenca con la detección de una población viable establecida en un sector del río Segura, si bien parece ser consecuencia de una introducción reciente. Proponemos tres hipótesis posibles en lo referente a la invasión de esta especie exótica: (1) Introducción deliberada o accidental por parte de pescadores deportivos; (2) Introducción de la especie en balsas de riego y la consecuente invasión del cauce principal debido al alto desarrollo agrícola característico del área donde se ha localizado la especie; (3) Introducción en la Cuenca a través del trasvase Tajo-Segura. El establecimiento de esta incipiente población sugiere la necesidad urgente de realizar estudios de seguimiento para el desarrollo de un Plan de Control de la misma.

Palabras clave: Lepomis gibbosus, Introducción, Exóticas, Segura, Península Ibérica.

\section{ABSTRACT}

This paper is the first reference of Lepomis gibbosus (L., 1758) in the Segura River basin (SE Spain). In this brief communication, the geographical distribution of L. gibbosus in Spain is widened to include the Segura River basin in its distribution rank. This is the first report of its occurrence in this basin, with the detection of a viable population in a section of the Segura rive although it seems to be a recent introduction. We propose three possible hypotheses concerning the invasion of this exotic species: (1) Deliberate or accidental introduction by anglers (Angling effect); (2) The introduction of the species into artificial irrigation ponds and the subsequent invasion of the main channel due to the high level o agricultural development in the area were the species was detectedft; (3) Introduction into the basin through the Tajo-Segura interbasin water transfer system. The establishment of this incipient population suggests that monitoring studies are urgently needed to develop a protocol for its control.

Keywords: Lepomis gibbosus, Introduction, Exotics, Segura, Iberian Peninsula.

Lepomis gibbosus (L., 1758) (Pisces, Centrarchidae) is a native fish from North America whose introduction in Europe dates from around 1880 (Vooren, 1972). This exotic fish is nowadays widespread in European waters (Welcomme, 1991). According to García-Berthou \& MorenoAmich (2000a) the first confirmed record of the species in the Iberian Peninsula (Lake Banyoles) dates to between 1910 and 1913. Until the 1980's the species remained under control although since then it has spread for a high number of hydrological basins in the Iberian Peninsula (De-Sostoa et al.,1987; Doadrio, 2002).
The aim of this note is to report the establishment of L. gibbosus in the Segura river basin. A total of 79 specimens were collected in seven out of a total of 15 sampling sites on the Segura River. The sample sites were located between Las Minas (upstream, Albacete 30SXH427557) and Azud de Ojós (downstream, Murcia 30SXH510469) (70 Km channel long). At each sampling locality (100-150 m long), fishing was performed with standard AC electrofishing equipment using a $1800 \mathrm{~W}$ generator (working voltage between 200 and $350 \mathrm{~V}, 2-3 \mathrm{~A}$ ) between May and June 2004. The specimens were fixed in 
neutralized formaldehyde solutions (10\%), sex and standard length $\left(\mathrm{L}_{\mathrm{S}} \pm 1 \mathrm{~mm}\right)$ were obtained for each individual ex situ. Some of them are preserved in the ichthiological collections of The Zoology and Anthropology Department of the University of Murcia (LgiSE04-1 / LgiSE04-25).

There are no previous records of $L$. gibbosus in the Segura River basin (Mas, 1986; García de Jalón et al., 1992; Torralva \& Oliva-Paterna, 1997; Torralva et al., 1999; Miñano et al., 2002 y 2003; Oliva-Paterna et al., 2002), however some of its population parameters point to a viable establishment of the species: (1) High occurrence $(46.6 \%$ of sampling sites) in a long strech of the Segura River (70 Km long channel); (2) Population size-structure and sex-ratio (Figure 1), although in comparison to other populations in the Iberian Peninsula (Zapata \& Granado-Lorencio, 1993; Godinho \& Ferreira, 1996; García-Berthou \& Moreno-Amich, 2000b; Gutiérrez-Estrada, 1997; GutiérrezEstrada et al., 2000), this seems to be an incipient population because of the lack of higher sizes and consequently old individuals; and (3) Confirmed reproduction, as seen by the capture of juveniles and mature adults (determined by visual observation of the gonads).
We hypothesize that the colonization of the Segura River by $L$. gibbosus may be attributed to either one or a combination of these three causes: (1) Its deliberate or accidental introduction by anglers since sport fishing is extremely popular in the sector of the river where the species has been detected (three intensive sport fishing preserves) and the popular use of the species as bait for sport fishing; (2) The sampling area is one of the most important irrigated agricultural areas of the Murcia region, and a network of artificial irrigation ponds has been developed. The anthropic introduction into such ponds of a variety of fish species is a very common and traditional practice; indeed agricultural activities have recently been shown to act as significant landscape determinants of non-indigenous fish invasion (Ross et al., 2001); (3) Consequence of fish dispersion along the Tajo-Segura interbasin water transfer system, such as has been demonstrated in the case of other introduced fish species in the Segura basin (García de Jalón et al., 1992; Torralva \& Oliva-Paterna, 1997).

The impact of biological invasions, particularly in the case of freshwater fish, is a worldwide ecological problem, which has not only been neglected (García-Berthou \& Moreno-Amich,

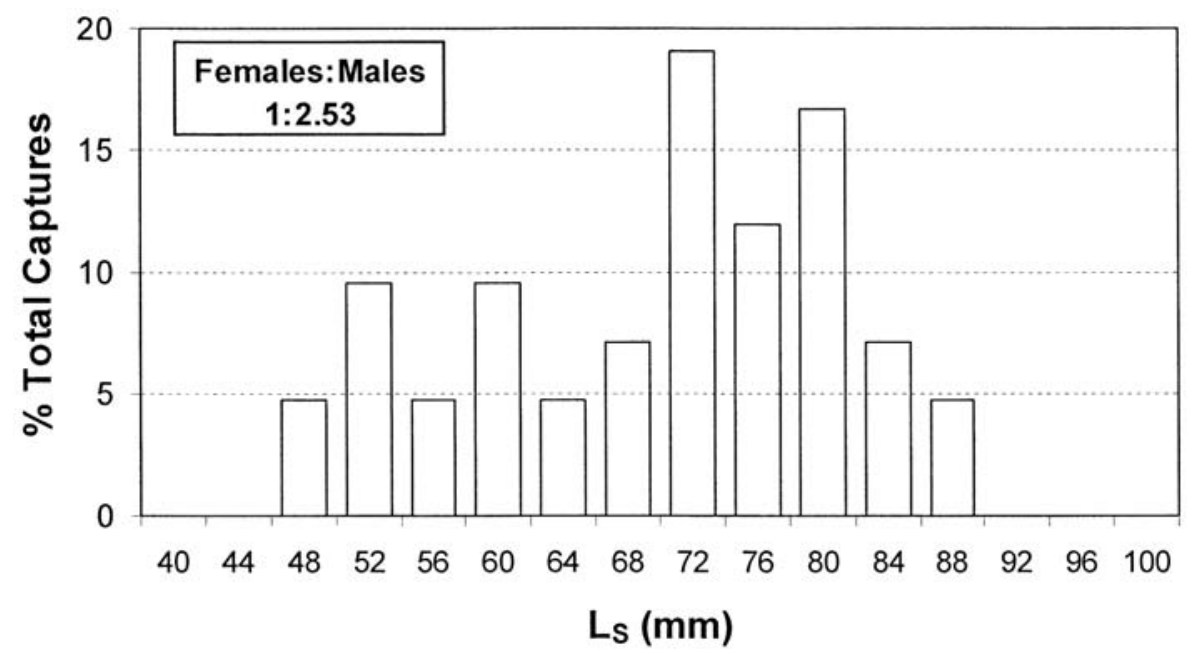

Figura 1. Distribución de frecuencias de longitud $\left(\mathrm{L}_{\mathrm{S}}, \mathrm{mm}\right)$ y proporción de sexos (machos/hembras) de la población de $L$. gibbosus detectada en el río Segura. Size-frequency distribution $\left(L_{S}, \mathrm{~mm}\right)$ and sex-ratio (males/females) of L. gibbosus population detected in the Segura River. 
2000a) but rather encouraged by the management activities of the administration (e.g. introduction of Oncorhynchus mykiss into intensive sport fishing preserves). In the Iberian Peninsula the negative effects of freshwater fish introduction has recently been demonstrated by several studies (Elvira, 1998; García-Berthou \& Moreno-Amich, 2000a; Godinho \& Ferreira, 2000; Elvira \& Almodóvar, 2001; Vila-Gispert et al., 2004). The most obvious potential impact of $L$. gibbosus introduction involves egg and juvenile fish predation (Gondinho et al., 1997; GarcíaBerthou \& Moreno-Amich, 2000b; Domínguez et al., 2002), which has been considered responsible for diminishing the reproductive capacity of other coexisting species (Keith \& Allardi, 1998). The detected population of L. gibbosus showed a low-density in relative terms compared with coexisting high-density species, such as Barbus sclateri and Chondrostoma polylepis, but this still represents a threat to other low-density coexisting species like Squalius pyrenaicus (= Leuciscus pyrenaicus). Moreover, some of these types of exotic species have spread quickly over extensive areas (Elvira, 1998).

In the last 25 years, eight non-autochthonous freshwater fish have become established in the Segura basin (García de Jalón et al., 1992; Torralva \& Oliva-Paterna, 1997 and 2003; Miñano et al., 2002), which, together with previously established non-autochthonous fish species, represent $76.5 \%$ of the current freshwater fish fauna of this basin. The actual impact of these non-autochthonous species, mainly exotic species to the Iberian Peninsula, on autochthonous fish is very difficult to ascertain because of the lack of previous (before introductions) and continuous (after introductions) data. Nonetheless, the viable establishment of this incipient population of $L$. gibbosus in the Segura River suggests that monitoring studies are urgently needed to develop a protocol for its control. In recent years, Spanish politics has become more environmentally conscious, but the Environmental services of the Autonomous Governments should now be forced to act in the control of the introduction and spread of exotic fish species.

\section{REFERENCES}

DE-SOSTOA, A., J. LOBÓN-CERVIÁ, V. FERNÁNDEZ-COLOMÉ \& F. J. DE-SOSTOA. 1987. La distribución del Pez-Sol (Lepomis gibbosus L.) en la Península Ibérica. Doñana, Acta Vertebrata, 14: 121-123.

DOADRIO, I. (Ed.) 2002. Atlas y Libro Rojo de los Peces Continentales de España. CSIC y Ministerio de Medio Ambiente, Madrid. 374 pp.

DOMÍNGUEZ, J., J. C. PENA, J. DE SOTO \& E. LUIS. 2002. Alimentación de dos poblaciones de perca sol (Lepomis gibbosus), introducidas en el Norte de España. Resultados Preliminares. Limnetica, 21(1-2): 135-144.

ELVIRA, B. 1998. Impact of introduced fish on the native freshwater fish fauna of Spain. In: Stocking and Introduction of Fish. I.G. Cowx (Ed.): 186190. Fishing News Books. Hull International Fisheries Institute, UK.

ELVIRA, B. \& A. ALMODÓVAR. 2001. Freshwater fish introduction in Spain: facts and figures at the beginning of the $21^{\text {st }}$ century. J. Fish Biol., 59 (Suppl. A): 323-331.

GARCÍA DE JALÓN, D., M. GONZÁLEZ DEL TÁNAGO \& C. CASADO. 1992. Ecology of regulated streams in Spain: An overview. Limnetica, 8: 161-166.

GARCÍA-BERTHOU, E. \& R. MORENO-AMICH. 2000a. Introduction of exotic fish into a Mediterranean lake over a 90-year period. Arch. Hydrobiol., 149(2): 271-284.

GARCÍA-BERTHOU, E. \& R. MORENO-AMICH. 2000b. Food of introduced pumpkinseed sunfish: ontogenetic diet shift and seasonal variation. $J$ Fish. Biol., 57: 29-40.

GODINHO, F. \& M. T. FERREIRA. 1996. The application of size-structure indices to Micropterus salmoides (Lacépède, 1802) and Lepomis gibbosus (L., 1758) populations as a management tool for southern Iberian reservoirs. Publ. Espec. Inst. Esp. Oceanogr., 21: 275-281.

GODINHO, F. \& M. T. FERREIRA. 2000. Composition of endemic fish assemblages in relation to exotic species and river regulation in a temperate stream. Biological Invasions, 2 (3): 231-244.

GONDINHO, F., M. T. FERREIRA \& R. V. CORTES. 1997. The environmental basis of diet variation in pumpkinseed sunfish, Lepomis gibbosus, and largemouth bass, Micropterus salmoides, 
along an Iberian river basin. Env. Bio. Fish., 50: 105-115.

GUTIÉRREZ-ESTRADA, J. C. 1997. Estructura por edades, crecimiento y biología reproductiva del pez sol (Lepomis gibbosa, L. 1758) en el río Guadiato (Córdoba). Tesis de Licenciatura. Universidad de Córdoba. 122 pp.

GUTIÉRREZ-ESTRADA, J. C., I. PULIDO-CALVO \& C. FERNÁNDEZ-DELGADO. 2000. Agestructure, growth and reproduction of the introduced pumpkinseed (Lepomis gibbosa, L. 1758) in a tributary of the Guadalquivir river (Southern Spain). Limnetica, 19: 21-29.

KEITH, P. \& J. ALLARDI. 1998. The introduced freshwater fish of France: status, impacts and management. In: Stocking and Introduction of Fish. I. G. Cowx (Ed.): 153-166. Fishing News Books. Hull International Fisheries Institute, UK.

MAS, J. 1986. La ictiofauna continental de la Cuenca del Río Segura, evolución histórica y estado actual. Anales de Biología, 8: 3-17.

MIÑANO, P. A., F. J. OLIVA-PATERNA \& M. TORRALVA. 2002. Primera cita de Sander lucioperca (L.) (Pisces, Percidae) en la Cuenca del Río Segura, S.E. de España. Anales de Biología, 24: 77-79.

MIÑANO, P. A., F. J. OLIVA-PATERNA, A. ANDREU, A. GARCÍA-MELLADO, J. GARCÍA-RODRÍGUEZ, D. GARCÍA DE JALÓN \& M. TORRALVA. 2003. Recursos piscícolas en los embalses de la Región de Murcia (SE de España). Bol. R. Soc. Esp. Hist. Nat. (Sec. Biol.), 98 (1-4): 103-113.

OLIVA-PATERNA, F. J., P. A. MIÑANO, A. ANDREU, A. GARCIA-MELLADO, C. FERNÁNDEZ-DELGADO \& M. TORRALVA. 2002. Distribución y Conservación del Fartet en Murcia. Quercus, 192: 38-42.
ROSS, R. M., W. A. LELLIS, R. M. BENNET \& C. S. JOHNSON. 2001. Landscape determinants of nonindigenous fish invasión. Biological Invasion, 3: 347-361.

TORRALVA, M. \& F. J. OLIVA-PATERNA. 1997. First record of Chondrostoma polylepis Steindachner, 1865 (Ostariophisi, Cyprinidae) in the basin of the river Segura, S.E. of Spain. Limnetica, 13(1): 1-3.

TORRALVA, M., N. A. UBERO-PASCAL, F. J. OLIVA-PATERNA \& J. MALO. 1999. Leuciscus pyrenaicus Günther, 1868 (Pisces, Cyprinidae) en la cuenca del Río Segura (S. E. de España). Zoologica Baetica, 10: 203-205.

TORRALVA, M. \& F. J. OLIVA-PATERNA. 2003. El Recurso íctico de las aguas continentales de la Región de Murcia. In: Los Recursos Naturales de la Región de Murcia: Un Análisis Interdisciplinar. M. A. Esteve, M. Llorens \& C. Martínez (eds.): 152-158. Universidad de Murcia, Servicio de Publicaciones. Murcia. España.

VILA-GISPERT, A., C. ALCARAZ \& E. GARCÍABERTHOU. 2005. Life-history traits of invasive fish in small Mediterranean streams. Biological Invasion. 7: 107-116.

VOOREN, C. M.1972. Ecological aspects of the introduction of fish species into natural habitats in Europe, with special reference to the Netherlands. A literature survey. J. Fish Biol., 4: 565-583.

WELCOMME, R. L. 1991. International introductions of freshwater fish species into Europe. Finnish Fisheries Research, 12: 256-264.

ZAPATA, S. \& C. GRANADO-LORENCIO. 1993. Age, growth and feeding of the exotic species Lepomis gibbosus in a Spanish cooling reservoir. Arch. Hydrobio./Suppl., 90(4): 561-573. 